\title{
Effects of Salicylic Acid and Indole Acetic Acid Exogenous Applications on Induction of Faba Bean Resistance against Orobanche crenata
}

\author{
Fatima Zahra Briache ${ }^{1,2}$, Mounia Ennami ${ }^{1}$, Joseph Mbasani-Mansi ${ }^{1,2}$, Assia Lozzi ${ }^{3}$, Abdelhadi Abousalim ${ }^{3}$, \\ Walid El Rodeny ${ }^{4}$, Moez Amri ${ }^{5}$, Zine El Abidine Triqui ${ }^{2}$, and Rachid Mentag (1) ${ }^{1 *}$ \\ ${ }^{1}$ Biotechnology Unit, CRRA-Rabat, National Institute of Agricultural Research (INRA), 10101, Rabat, Morocco \\ ${ }^{2}$ Department of Biotechnology and Plant Physiology, Faculty of Sciences, Mohammed V University, 1014, Rabat, Morocco \\ ${ }^{3}$ Department of Crop Production, Protection and Biotechnology, Institute of Agronomy and Veterinary Medicine Hassan \\ II, 6356, Rabat, Morocco \\ ${ }^{4}$ Sakha Agricultural Research Station, Agricultural Research Center (ARC), 33717, Kafr El-Sheikh, Egypt \\ ${ }^{5}$ Agro-sciences (AgBS), University Mohammed VI Polytechnic (UM6P), 43150, Benguerir, Morocco
}

(Received on March 18, 2020; Revised on July 29, 2020; Accepted on August 6, 2020)

The parasitic weed, Orobanche crenata, is one of the most devastating constraint for faba bean production in Mediterranean regions. Plant host defense induction was reported as one of the most appropriate control methods in many crops. The aim of this study was to elucidate the effect of salicylic acid (SA) and indole acetic acid (IAA) on the induction of faba bean resistance to $O$. crenata under the field and controlled experimental conditions. Both hormones were tested on two contrasting faba bean genotypes: Giza 843 (partially resistant to $O$. crenata) and Lobab (susceptible) at three different application methods (seed soaking, foliar spray, and the combination of both seed soaking and foliar spray). Soaking seeds in SA or IAA provided the highest protection levels reaching $\sim 75 \%$ compared to the untreated control plants. Both elicitors limited the chlorophyll content decrease caused by $O$. crenata infestation and increased phenolic compound production in host plants. Phenylalanine ammonia lyase, peroxidase, and polyphenol oxidase activities were stimulated in the

\footnotetext{
*Corresponding author.

FAX) +212-537775530

E-mail) rachidmentag@yahoo.ca

ORCID

Rachid Mentag

https://orcid.org/0000-0002-2040-637X

(c) This is an Open Access article distributed under the terms of the Creative Commons Attribution Non-Commercial License (http:// creativecommons.org/licenses/by-nc/4.0) which permits unrestricted noncommercial use, distribution, and reproduction in any medium, provided the original work is properly cited.
}

Articles can be freely viewed online at www.ppjonline.org. host plant roots especially in the susceptible genotype Lobab. The magnitude of induction was more obvious in infested than in non-infested plants. Histological study revealed that both SA and IAA decreased the number of attached $O$. crenata spikes which could be related to specific defense responses in the host plant roots.

Keywords : faba bean, indole acetic acid, induction of resistance, Orobanche crenata, salicylic acid

Handling Editor : Kee Hoon Sohn

Broomrapes (Orobanche spp.) are obligate root holoparasitic plants devoid of chlorophyll and completely depend on the host plants for their supply of carbon, nitrogen and inorganic solutes (Fernández-Aparicio et al., 2016). Consequently, they cause severe yield losses on infested crops (up to $100 \%$ ) especially in the drier and warmer areas of Europe, Africa and Asia where it is reported to parasitize a wide range of economically important hosts including legumes, sunflower, tomato and tobacco (Habimana et al., 2014). Among these parasitic plants, O. crenata is considered to be the most devastating specie affecting faba bean in Morocco. Abu-Irmaileh and Labrada (2014) reported that legume crop infestation by $O$. crenata in Morocco has increased from $12 \%$ in 1981 to $51 \%$ in 2003 .

Several strategies have been used to control Orobanche including cultural practices, chemical and biological methods (Habimana et al., 2014). However, due to the particular characteristics of this parasitic weed (underground devel- 
opment and attachment to the host roots), the available control strategies have not proven as economical, environmental, and applicable as predicted (Pérez-de-Luque et al., 2010). Therefore, alternative sustainable strategies for crop protection against pathogens were developed (Walters et al., 2013). These approaches involve the activation of the plants' natural defense responses through the use of different types of inducers, also called elicitors (Burdziej et al., 2019; Raasch-Fernandes et al., 2019; Ramakrishna et al., 2019; Walters et al., 2013). These inducers of resistance stimulate natural defense mechanisms of host plants, leading to a systemic acquired resistance (SAR) (Monci et al., 2019; Thakur and Sohal, 2013). The SAR in plants is often associated with various cellular defense responses including cell wall reinforcement, phenolic production such as phytoalexins and induction of some enzymes activities like pathogenesis-related proteins (PR) (Ryals et al., 1996).

Durrant and Dong (2004) reported that SAR induction is controlled by an endogenous accumulation of salicylic acid that is synthesized locally and systemically leading to transcriptional activation of the PR genes. Moreover, an increase in the concentration of phenolic compounds and the activity of phenol metabolizing enzymes such as peroxidase (POX), polyphenol oxidase (PPO), and phenylalanine ammonia lyase (PAL) in response to salicylic acid (SA) activity were also reported (Clarke et al., 2000; Thakur and Sohal, 2013). Other studies showed that indole acetic acid (IAA), a phytohormone auxin, which has been known to be a regulator of plant growth and development ever since its discovery, also shows an important role in the defense process against biotic stress (Al-Wakeel et al., 2013; Gravel et al., 2007; Ueno et al., 2011).

Over the last two decades, several studies have promoted the development of different synthetic elicitors, including SA and benzothiadiazole (BTH), and show how exogenous treatments of plants with these compounds can induce resistance, both locally and systemically, to subsequent pathogen attacks (Triki et al., 2018; Walters and Fountaine, 2009). Induced systemic acquired resistance, by the application of exogenous chemical agents, against different Orobanche species has been reported in a number of crops (Abbes et al., 2014; Gonsior et al., 2004; Kusumoto et al., 2007; Pérez-de-Luque et al., 2004; Sauerborn et al., 2002; Triki et al., 2018). Pérez-de-Luque et al. (2004) reported the effectiveness of BTH (1,2,3-benzothiadiazole-7-carbothioic acid S-methyl ester) foliar application in decreasing $O$. crenata infestation in pea under field conditions. O. $m i$ nor control by SA and BTH root application has also been reported on red clover grown in plastic house by inhibition of $O$. minor radicles elongation and lignification of the host root endodermis (Kusumoto et al., 2007). The effectiveness of SA and BTH treatments was also observed in faba bean infested by $O$. foetida (Abbes et al., 2014; Triki et al., 2018). In sunflower, seed treatment by BTH increased the level of resistance against $O$. cumana which was mainly associated with an activation of phytoalexin, $\mathrm{H}_{2} \mathrm{O}_{2}$ and chitinase protein production (Sauerborn et al., 2002). These studies demonstrate that application of defense elicitors could be a very promising and environmental friendly option to control broomrapes. However, the efficiency of the application of theses elicitors and their use depend on a number of factors that need to be taken into consideration, such as the application method, dose and frequency of elicitor application, host plant and the growth stage of both the host and the parasite (Walters et al., 2013).

This study aims to evaluate (1) the effect of two potential elicitors SA and IAA on $O$. crenata infestation level in faba bean under both field and controlled conditions and (2) the associated biochemical and histological changes in host plants.

\section{Materials and Methods}

Plant material. Two faba bean genotypes were used in this study; Giza 843 genotype which is partially resistant to $O$. crenata selected in Egypt (Abd El-Aty et al., 2016) and the susceptible genotype Lobab (selected in Morocco). The $O$. crenata seeds used in the controlled condition experiments were collected from some Orobanche spikes parasite on faba bean plants grown at INRA Marchouch experimental station in Morocco.

Field evaluation trial. The trial was conducted during the cropping season 2016/17 in a sick plot highly infested by $O$. crenata at Marchouch research station - Morocco. This field plot was mainly cultivated with faba bean and had a history of naturally, heavy and uniform infestation level with $O$. crenata. Both faba bean genotypes with different treatments were planted at the end of November according to randomized complete block design with five replications. Each genotype was planted in eight rows of 2 $\mathrm{m}$ length and $0.5 \mathrm{~m}$ inter-row spacing. Eight different treatment groups were categorized including infested control check, non-infested control (treated with glyphosate) and 6 treatments using different plant defense inducers and application methods. Those treatments are described in the Table 1.

Hand hoeing was done when required and no fertilizers were applied. At crop maturity (end of May), several parameters referring to Orobanche infestation level and host 
Table 1. Different treatments applied in field

\begin{tabular}{cl}
\hline Treatment & \multicolumn{1}{c}{ Protocol } \\
\hline T1 & Seeds soaked during 6 h in 1 mM SA \\
T2 & Seeds soaked during 6 h in 0.09 mM IAA \\
T3 & Spraying plant with 1 mM SA in end of January (before flowering stage) \\
T4 & Spraying plant with 0.09 mM IAA in end of January (before flowering stage) \\
T5 & Seeds soaked during 6 h in 1 mM SA + spraying plant with 1 mM SA \\
T6 & Seeds soaked during 6 h in 0.09 mM IAA + spraying plant with 0.09 mM IAA \\
T7 & Spraying plant with glyphosate at dose 80 g/ha \\
C & Non treated (infested control) \\
\hline
\end{tabular}

SA, salicylic acid; IAA, indole acetic acid.

development were determined. Thus, $O$. crenata infestation was estimated by counting the number of emerged spikes per host plant then measuring their dry weight. Also, the incidence (percentage of host plants showing emerged spikes), the percentage of $O$. crenata infestation reduction (calculated using the formula: $O$. crenata spikes number in infested control $-O$. crenata spikes number in treated plant/O. crenata spikes number in infested control 100), and the severity (provides information on the impact of the parasite on host vigor using 1-9 scale (Abbes et al., 2007) were determined. Agronomic traits including seed yield per plant, shoot dry weight of the host plant, and 100 seeds weight were also recorded.

Pot experiment. An experiment was conducted under controlled conditions at $25 \pm 2{ }^{\circ} \mathrm{C}, 16: 8$ day/night photoperiod, and $60-70 \%$ relative humidity. The two faba bean genotypes were grown in 61 pots filled with sterilized soil, either inoculated or not with $20 \mathrm{mg}$ of $O$. crenata seeds per kilogram of soil. Thus, two different sets of pots, infested and non-infested, were prepared. Each set was subdivided into seven groups, one untreated group served as control and the other six groups were subjected to different treatments using plant defense inducers as described in Table 1. In this experiment, glyphosate treatment was not used. All pots were arranged in randomized complete block design with five replications. Four months after sowing, faba bean plants were removed from the pots. Roots were gently washed under running tap water and several parameters referring to infestation level and host plant development were assessed. Thus, the number of $O$. crenata infestation events per plant was determined by counting the following developmental stages: $\mathrm{S} 3$, tubercles $>2 \mathrm{~mm}$ without root formation; S4, tubercles with crown-root; S5, stage spider; S6, sprout already visible remaining underground; S7, start development of spike; S8, flowering and setting of seeds (Briache et al., 2019). Also, the total O.crenata dry weight, the dry weight of host shoot and roots per faba bean plant were measured. Fresh leaves and root samples were stored at $-70^{\circ} \mathrm{C}$ for biochemical assays.

Extraction and quantification of chlorophyll pigments. Extraction of chlorophyll $a$ and $b$ from fully expanded fresh leaves was carried out according to Fadeel (1962) with slight modifications. For the different treatments, leaves were taken randomly from the third node of the main shoot for all the plants. Two hundred milligrams of fresh leaves was homogenized with mortar and pestle in $2.5 \mathrm{ml}$ of $100 \%$ acetone. The homogenate was centrifuged at $12,000 \times g$ for $10 \mathrm{~min}$ at $4^{\circ} \mathrm{C}$ and the supernatant was used to measure the absorbance at $645 \mathrm{~nm}$ and $664 \mathrm{~nm}$. Total chlorophyll contents $(\mathrm{a}+\mathrm{b})$ were calculated using the equation represented by Sesták (1971).

Extraction and quantification of phenolic compounds. Extraction of phenolic compounds from dried roots of healthy and infested treated plants was carried out as described by $\mathrm{Xu}$ and Chang (2007) and their content was determined by a Folin-Ciocalteu assay (Singleton et al., 1999) using gallic acid as standard. The absorbance was measured at $750 \mathrm{~nm}$ and total phenolic content was calculated from gallic acid standard curve then expressed as $\mathrm{mg} /$ g root dry weight.

Extraction and determination of phenylalanine ammonia-lyase PAL activity. Extraction and assay of PAL were carried out according to Solecka and Kacperska (2003) using fresh root tissues from healthy and infested treated plants. PAL activity was determined by measuring the absorbance at $290 \mathrm{~nm}$ and expressed as EU/mg root fresh weight/h (one unit of enzyme activity equals the amount of PAL that produced $1 \mu \mathrm{M}$ of trans-cinnamic acid in $1 \mathrm{~h}$ ).

Extraction and determination of POX activity. This test 
was carried out, using fresh root tissues from healthy and infested treated plants, according to the method outlined by Polle et al. (1994). POX activity was determined by measuring the absorbance at $470 \mathrm{~nm}$, and expressed as EU/mg root fresh weight/min (U: $\mu \mathrm{M}$ tetragaiacol produced per minute).

Extraction and determination of PPO activity. Extraction and assay of PPO were carried out, using fresh root tissues from healthy and infested treated plants, as described by Al-Wakeel et al. (2013). PPO activity was determined by measuring the absorbance at $410 \mathrm{~nm}$ and expressed as $\mathrm{EU} / \mathrm{mg}$ root fresh weight $/ \mathrm{min}$.

Histological study. Faba bean root segments with attached Orobanche tubercles were taken from treated and untreated plants and placed for $48 \mathrm{~h}$ in formaldehyde-acetic acid fixative solution (ethanol 50\% + formaldehyde 5\% + glacial acetic acid $10 \%$, in water). The fixed segments were dehydrated in ethanol series $(50 \%, 80 \%, 95 \%, 100 \%, 100 \%$ :

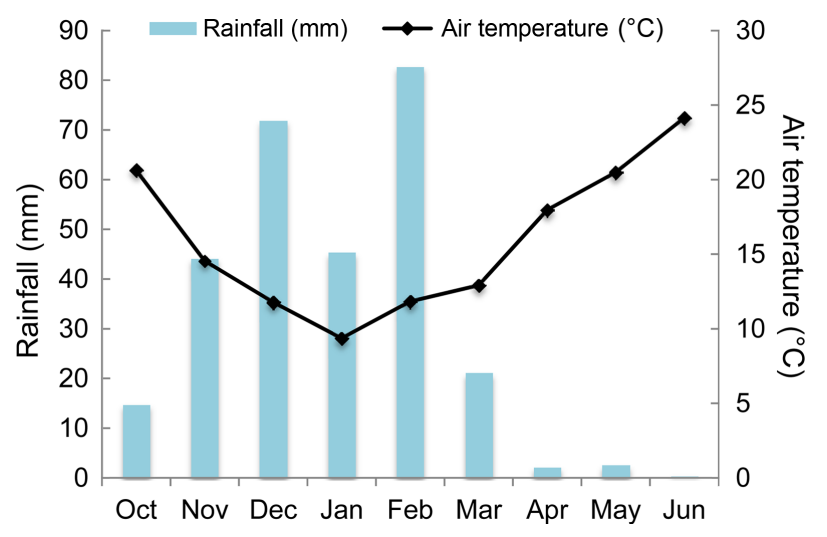

Fig. 1. Average air temperature $\left({ }^{\circ} \mathrm{C}\right)$ and rainfall $(\mathrm{mm})$ during the cropping season 2016/2017 at Marchouch experimental station of INRA-Morocco.

$12 \mathrm{~h}$ for each) then transferred to an embedding solvent via xylene-ethanol series $(30 \%, 50 \%, 80 \%, 100 \%, 100 \% 12 \mathrm{~h}$ each) and finally saturated with paraffin. Sections of $5 \mu \mathrm{m}$ thickness were cut with a rotary microtome Leica (Nuss-

Table 2. Infestation parameters recorded for the two studied genotypes under different treatments in a high Orobanche crenata infested field

\begin{tabular}{|c|c|c|c|c|c|c|}
\hline Genotype & $\begin{array}{l}\text { Host plant } \\
\text { treatment }\end{array}$ & $\begin{array}{c}\text { Incidence }^{\mathrm{a}} \\
(\%)\end{array}$ & $\begin{array}{l}\text { O. crenata } \\
\text { infestation } \\
\text { reduction }(\%)\end{array}$ & Severity ${ }^{\mathrm{b}}$ & $\begin{array}{l}\text { No. of emerged } \\
\text { O. crenata spikes } \\
\text { per host plant }\end{array}$ & $\begin{array}{l}\text { O. crenata spikes } \\
\text { dry weight per host } \\
\text { plant }(\mathrm{g})\end{array}$ \\
\hline \multirow[t]{8}{*}{ Lobab } & $\mathrm{C}$ & $90.47 \pm 6.4 \mathrm{a}$ & $0 \pm 0 \mathrm{e}$ & $7 \pm 0.1 \mathrm{a}$ & $4.22 \pm 0.6 \mathrm{a}$ & $5.68 \pm 0.3 \mathrm{a}$ \\
\hline & $\mathrm{T} 7$ & $0 \pm 0 \mathrm{e}$ & $100 \pm 0 \mathrm{a}$ & $1 \pm 0 \mathrm{~d}$ & $0 \pm 0 \mathrm{e}$ & $0 \pm 0 \mathrm{~d}$ \\
\hline & $\mathrm{T} 1$ & $44.76 \pm 7.1 \mathrm{~cd}$ & $76.3 \pm 8.1 b$ & $1.8 \pm 0.3 \mathrm{~cd}$ & $1 \pm 0.1 \mathrm{de}$ & $2.08 \pm 0.4 \mathrm{c}$ \\
\hline & $\mathrm{T} 2$ & $53.42 \pm 6.4 \mathrm{bcd}$ & $63.2 \pm 7.7 b c$ & $3.4 \pm 0.8 b c$ & $1.55 \pm 0.3 \mathrm{cde}$ & $2.4 \pm 1 \mathrm{c}$ \\
\hline & $\mathrm{T} 3$ & $83.21 \pm 8.5 \mathrm{a}$ & $27 \pm 2$ cde & $5.4 \pm 0.4 \mathrm{ab}$ & $3.08 \pm 0.5 \mathrm{ab}$ & $3.58 \pm 0.6 \mathrm{abc}$ \\
\hline & $\mathrm{T} 4$ & $84.12 \pm 10.9 \mathrm{a}$ & $13 \pm 1.4$ cde & $6.4 \pm 0.6 \mathrm{a}$ & $3.67 \pm 0.3 \mathrm{ab}$ & $4.64 \pm 0.8 \mathrm{ab}$ \\
\hline & $\mathrm{T} 5$ & $57.38 \pm 5.5 \mathrm{bcd}$ & $63.9 \pm 9.8 \mathrm{bc}$ & $2.6 \pm 0.5 \mathrm{bcd}$ & $1.52 \pm 0.2 \mathrm{cde}$ & $3.10 \pm 0.7 b c$ \\
\hline & T6 & $60.71 \pm 6.5 \mathrm{bc}$ & $49.5 \pm 4.4 \mathrm{c}$ & $3.8 \pm 1 b c$ & $2.13 \pm 0.3 b c$ & $3.11 \pm 0.5 \mathrm{bc}$ \\
\hline \multirow[t]{8}{*}{ Giza 843} & $\mathrm{C}$ & $45.35 \pm 8.7 \mathrm{c}$ & $0 \pm 0 \mathrm{e}$ & $3.66 \pm 1 b$ & $1.46 \pm 0.3 \mathrm{c}$ & $2.29 \pm 0.8 \mathrm{c}$ \\
\hline & $\mathrm{T} 7$ & $0 \pm 0 \mathrm{e}$ & $100 \pm 0 \mathrm{a}$ & $1 \pm 0 \mathrm{~d}$ & $0 \pm 0 \mathrm{e}$ & $0 \pm 0 \mathrm{~d}$ \\
\hline & $\mathrm{T} 1$ & $22.38 \pm 5.1 \mathrm{~d}$ & $69.1 \pm 9.4 b$ & $1.4 \pm 1 \mathrm{~cd}$ & $0.45 \pm 0.05 \mathrm{e}$ & $0.78 \pm 0.2 \mathrm{~cd}$ \\
\hline & $\mathrm{T} 2$ & $21.83 \pm 6.2 \mathrm{~d}$ & $74 \pm 6.7 \mathrm{~b}$ & $1 \pm 0 \mathrm{~cd}$ & $0.38 \pm 0.1 \mathrm{e}$ & $0.74 \pm 0.3 \mathrm{~cd}$ \\
\hline & $\mathrm{T} 3$ & $49.83 \pm 3.2 \mathrm{bcd}$ & $19.1 \pm 3.1 \mathrm{cde}$ & $2.2 \pm 0.3 \mathrm{bcd}$ & $1.18 \pm 0.2 \mathrm{cde}$ & $1.63 \pm 0.4 \mathrm{~cd}$ \\
\hline & $\mathrm{T} 4$ & $33.21 \pm 5.1 \mathrm{cde}$ & $23.9 \pm 5$ cde & $1.8 \pm 0.1 \mathrm{bcd}$ & $1.11 \pm 0.1 \mathrm{cde}$ & $2.69 \pm 1.2 \mathrm{c}$ \\
\hline & $\mathrm{T} 5$ & $21.44 \pm 4.3 \mathrm{~d}$ & $50.6 \pm 7.5 \mathrm{c}$ & $1.4 \pm 0.2 \mathrm{~cd}$ & $0.72 \pm 0.3 \mathrm{de}$ & $1.39 \pm 0.6 \mathrm{~cd}$ \\
\hline & T6 & $27.16 \pm 7.5 \mathrm{de}$ & $73.2 \pm 9.4 b$ & $1 \pm 0 \mathrm{~cd}$ & $0.39 \pm 0.05 \mathrm{e}$ & $0.51 \pm 0.1 \mathrm{~d}$ \\
\hline
\end{tabular}

Values are presented as mean \pm SE of five replications. Data in a column followed by different letters are significantly different at the 0.05 levels by Duncan's test.

ancidence: percentage (\%) of faba bean plants presenting emerged $O$. crenata spikes per row.

beverity scale (1, absence or few emerged spikes without any Orobanche seed production; 3, sporadic emerged spikes [no more than two per plant] but with few Orobanche seed production; 5, more than two emerged spikes per host plant with average Orobanche seed production and an almost normal plant growth; 7, many emerged spikes (three to five) per plant, with normal Orobanche growth and seed production and significant growth and grain yield reduction of the host; 9, very important number of emerged spikes per plant, abundant Orobanche seed production and serious reduction of host grain yield or complete destruction of the host). 
loch, Germany) and attached to adhesive-treated microscope slides. After removal of the paraffin, the staining of sections was carried out with $1 \%$ toluidine blue according to the method outlined by Goldwasser et al. (2000). The slides were dried and mounted with $\operatorname{DePeX}(\mathrm{BDH})$ and the sections were observed under a Euromex ZE-1657 stereomicroscope (Arnhem, Netherlands).

Statistical analysis. Statistical analysis of studied parameters was cried out using SPSS software version 21 (IBM Corp., Armonk, NY, USA). All data were subjected to variance analysis of (ANOVA). Treatment means were compared by Duncan's test at $P=0.05$.

\section{Results}

Effects of elicitor treatments on $O$. crenata infestation and host development in the field. High $O$. crenata infestation level occurred during the cropping season $2016 / 2017$. This cropping season was characterized by mild temperature $\left(10-12^{\circ} \mathrm{C}\right.$ average air temperature) and sufficient water supply during winter $(150 \mathrm{~mm})$ (Fig. 1). These favorable climatic conditions induced and improved O. crenata attachment and growth on the host plant roots. Thus, untreated plants of susceptible genotype (Lobab) showed high infestation level with $90.47 \%$ as incidence, 7 as severity, 4.22 emerged $O$. crenata spikes per plant and
$5.68 \mathrm{~g}$ of $O$. crenata spikes dry weight per host plant. Compared to this susceptible genotype, untreated resistant genotype (Giza 843) showed low O. crenata infestation level presented by $45.35 \%$ as incidence, 3.66 as severity, 1.46 emerged $O$. crenata spikes per plant and $2.29 \mathrm{~g}$ of $O$. crenata spikes dry weight per host plant (Table 2). Application of glyphosate allowed a complete control of this infestation in both genotypes. Furthermore, different application methods of SA $(1 \mathrm{mM})$ or IAA $(0.09 \mathrm{mM})$ generated variable effects on $O$. crenata infestation (Table 2). Thus, soaking seeds in SA or IAA solutions before sowing (T1 and T2 treatments) as well as application of a double treatment (T5 and T6 treatments) significantly reduced $(P<0.05) O$. crenata infestation in both studied genotypes. Compared to untreated plants, reduction of $O$. crenata emergence on both Lobab and Giza 843 treated plants ranged from $63 \%$ to $76.3 \%$ when $\mathrm{T} 1$ or $\mathrm{T} 2$ was applied, and from $49.5 \%$ to $73.2 \%$ when T5 or T6 was applied. However, no significant effect on infestation level was observed when $\mathrm{T} 3$ and T4 were applied.

Results also showed that for both studied genotypes, no significant effect of SA or IAA treatments was recorded on shoot dry matter production (Table 3 ). For plants subjected to T6 treatment, leaf yellowing and necrosis were observed. Seed pre-treatment with resistance inducers SA or IAA resulted in a seed yield increase for both studied genotypes. Compared to untreated plant, respective yield increases of

Table 3. Shoot dry matter production, seed yield and 100 seed weight recorded for the two studied genotypes under different treatments in a high Orobanche crenata infested field

\begin{tabular}{|c|c|c|c|c|}
\hline Genotype & Host plant treatment & Shoot dry weight/plant (g) & Seed yield/plant $(\mathrm{g})$ & 100 Seeds weight $(\mathrm{g})$ \\
\hline \multirow{8}{*}{ Lobab } & $\mathrm{C}$ & $12.14 \pm 2.2 \mathrm{a}$ & $4.18 \pm 1.6 \mathrm{c}$ & $84.77 \pm 8.2 \mathrm{a}$ \\
\hline & $\mathrm{T} 7$ & $10.70 \pm 1.2 \mathrm{ab}$ & $7.30 \pm 1.1 \mathrm{~b}$ & $81.50 \pm 0.7 \mathrm{a}$ \\
\hline & $\mathrm{T} 1$ & $9.71 \pm 1.1 \mathrm{ab}$ & $8.75 \pm 2.7 b$ & $86.63 \pm 4.3 \mathrm{a}$ \\
\hline & $\mathrm{T} 2$ & $11.08 \pm 2.1 \mathrm{a}$ & $6.41 \pm 1.2 \mathrm{~b}$ & $67.28 \pm 11.2 \mathrm{ab}$ \\
\hline & $\mathrm{T} 3$ & $7.86 \pm 0.4 \mathrm{ab}$ & $5.07 \pm 2.2 \mathrm{c}$ & $86.65 \pm 4.1 \mathrm{a}$ \\
\hline & $\mathrm{T} 4$ & $8.96 \pm 0.6 \mathrm{ab}$ & $7.85 \pm 2.8 b$ & $85.88 \pm 3.9 \mathrm{a}$ \\
\hline & T5 & $9.68 \pm 1.4 \mathrm{ab}$ & $5.09 \pm 1.8 \mathrm{c}$ & $76.3 \pm 5.5 \mathrm{a}$ \\
\hline & $\mathrm{T} 6$ & $4.52 \pm 1.1 \mathrm{~b}$ & $3.75 \pm 1.7 \mathrm{c}$ & $47.59 \pm 10.8 b$ \\
\hline \multirow[t]{8}{*}{ Giza 843} & $\mathrm{C}$ & $9.36 \pm 0.8 \mathrm{ab}$ & $11.82 \pm 1.9 \mathrm{~b}$ & $86.68 \pm 3.6 \mathrm{a}$ \\
\hline & $\mathrm{T} 7$ & $10.70 \pm 0.4 \mathrm{ab}$ & $12.73 \pm 0.3 \mathrm{a}$ & $61.27 \pm 1.1 \mathrm{ab}$ \\
\hline & $\mathrm{T} 1$ & $9.36 \pm 0.6 \mathrm{ab}$ & $12.62 \pm 2.5 \mathrm{a}$ & $81.20 \pm 3.1 \mathrm{a}$ \\
\hline & $\mathrm{T} 2$ & $8.07 \pm 0.4 \mathrm{ab}$ & $13.40 \pm 1.8 \mathrm{a}$ & $75.28 \pm 3 \mathrm{ab}$ \\
\hline & $\mathrm{T} 3$ & $9.94 \pm 2 \mathrm{ab}$ & $11.73 \pm 2.6 b$ & $74.86 \pm 2.7 \mathrm{ab}$ \\
\hline & $\mathrm{T} 4$ & $11.22 \pm 0.6 \mathrm{a}$ & $15.10 \pm 2.4 \mathrm{a}$ & $74.43 \pm 1.8 \mathrm{ab}$ \\
\hline & T5 & $11.31 \pm 1.8 \mathrm{a}$ & $13.90 \pm 2.5 \mathrm{a}$ & $71.77 \pm 4.3 \mathrm{ab}$ \\
\hline & T6 & $8.82 \pm 0.7 \mathrm{ab}$ & $11.48 \pm 2.1 \mathrm{~b}$ & $71.12 \pm 6.2 \mathrm{ab}$ \\
\hline
\end{tabular}

Values are presented as mean \pm SE of five replications. Data in a column followed by different letters are significantly different at the 0.05 levels by Duncan's test. 
Table 4. Infestation parameters recorded for the two studied genotypes under different treatments in pot assay

\begin{tabular}{|c|c|c|c|c|c|c|c|c|}
\hline \multirow{2}{*}{ Genotype } & \multirow{2}{*}{$\begin{array}{l}\text { Host plant } \\
\text { treatment }\end{array}$} & \multicolumn{5}{|c|}{ No. of Orobanche crenata infestation events/developmental stage } & \multirow{2}{*}{$\begin{array}{c}\text { Total no. of } \\
\text { O. crenata } \\
\text { infestation event }\end{array}$} & \multirow{2}{*}{$\begin{array}{l}\text { Total } O \text {. crenata } \\
\text { dry weight }(\mathrm{g})\end{array}$} \\
\hline & & $\mathrm{S} 3$ & S4 & S5 & S6 & S7 & & \\
\hline \multirow[t]{7}{*}{ Lobab } & $\mathrm{C}$ & $0.0 \pm 0 \mathrm{~b}$ & $3.3 \pm 0.7 \mathrm{a}$ & $3.3 \pm 0.8 \mathrm{~b}$ & $10.0 \pm 2.2 \mathrm{a}$ & $6.6 \pm 1.1 \mathrm{a}$ & $23.3 \pm 2.1 \mathrm{a}$ & $4.8 \pm 1.3 \mathrm{a}$ \\
\hline & $\mathrm{T} 1$ & $0.0 \pm 0 \mathrm{~b}$ & $0.0 \pm 0 \mathrm{~b}$ & $0.0 \pm 0 \mathrm{~b}$ & $0.0 \pm 0 \mathrm{~b}$ & $0.0 \pm 0 \mathrm{~b}$ & $0.0 \pm 0 \mathrm{c}$ & $0.0 \pm 0 \mathrm{~b}$ \\
\hline & $\mathrm{T} 2$ & $0.0 \pm 0 \mathrm{~b}$ & $0.0 \pm 0 \mathrm{~b}$ & $4.5 \pm 0.2 \mathrm{~b}$ & $1.0 \pm 0.2 \mathrm{~b}$ & $1.0 \pm 0.09 \mathrm{~b}$ & $6.5 \pm 0.8 \mathrm{~b}$ & $0.4 \pm 0.07 \mathrm{~b}$ \\
\hline & $\mathrm{T} 3$ & $0.0 \pm 0 \mathrm{~b}$ & $3.3 \pm 0.09 \mathrm{a}$ & $10.0 \pm 4.3 \mathrm{a}$ & $3.6 \pm 0.5 b$ & $0.3 \pm 0.07 \mathrm{~b}$ & $17.3 \pm 1.3 \mathrm{a}$ & $1.6 \pm 0.8 \mathrm{ab}$ \\
\hline & $\mathrm{T} 4$ & $0.0 \pm 0 \mathrm{~b}$ & $5.5 \pm 0.8 \mathrm{a}$ & $4.0 \pm 0.6 \mathrm{~b}$ & $1.0 \pm 0.3 \mathrm{~b}$ & $0.0 \pm 0 \mathrm{~b}$ & $10.5 \pm 1.5 \mathrm{ab}$ & $0.8 \pm 0.3 \mathrm{~b}$ \\
\hline & T5 & $0.0 \pm 0 \mathrm{~b}$ & $0.0 \pm 0 \mathrm{~b}$ & $0.0 \pm 0 \mathrm{~b}$ & $0.0 \pm 0 \mathrm{~b}$ & $0.0 \pm 0 \mathrm{~b}$ & $0.0 \pm 0 \mathrm{c}$ & $0.0 \pm 0 \mathrm{~b}$ \\
\hline & T6 & $0.5 \pm 0.07 b$ & $3.3 \pm 0.1 \mathrm{a}$ & $0.3 \pm 0.1 \mathrm{~b}$ & $2.6 \pm 1 \mathrm{~b}$ & $0.0 \pm 0 \mathrm{~b}$ & $6.8 \pm 0.5 b$ & $0.2 \pm 0.02 b$ \\
\hline \multirow[t]{7}{*}{ Giza 843} & $\mathrm{C}$ & $0.0 \pm 0 \mathrm{~b}$ & $0.0 \pm 0 \mathrm{~b}$ & $8.0 \pm 1 \mathrm{a}$ & $1.0 \pm 0.08 b$ & $0.0 \pm 0 \mathrm{~b}$ & $9.0 \pm 0.9 \mathrm{ab}$ & $0.4 \pm 0.05 b$ \\
\hline & $\mathrm{T} 1$ & $0.0 \pm 0 \mathrm{~b}$ & $1.5 \pm 0.1 \mathrm{~b}$ & $0.0 \pm 0 \mathrm{~b}$ & $0.5 \pm 0.1 b$ & $0.0 \pm 0 \mathrm{~b}$ & $2.0 \pm 0.04 \mathrm{c}$ & $0.2 \pm 0.03 b$ \\
\hline & $\mathrm{T} 2$ & $1.0 \pm 0.02 \mathrm{a}$ & $3.0 \pm 0.4 \mathrm{a}$ & $0.0 \pm 0 \mathrm{~b}$ & $0.0 \pm 0 \mathrm{~b}$ & $0.0 \pm 0 \mathrm{~b}$ & $4.0 \pm 0.1 \mathrm{c}$ & $0.1 \pm 0.02 b$ \\
\hline & $\mathrm{T} 3$ & $1.3 \pm 0.3 \mathrm{a}$ & $5.0 \pm 0.8 \mathrm{a}$ & $0.0 \pm 0 \mathrm{~b}$ & $0.0 \pm 0 \mathrm{~b}$ & $0.0 \pm 0 \mathrm{~b}$ & $6.3 \pm 0.1 b$ & $0.5 \pm 0.04 \mathrm{~b}$ \\
\hline & $\mathrm{T} 4$ & $0.0 \pm 0 \mathrm{~b}$ & $2.0 \pm 0.4 \mathrm{~b}$ & $1.0 \pm 0.4 \mathrm{~b}$ & $2.0 \pm 0.8 \mathrm{~b}$ & $0.5 \pm 0.07 b$ & $5.5 \pm 0.5 \mathrm{~b}$ & $0.4 \pm 0.1 \mathrm{~b}$ \\
\hline & $\mathrm{T} 5$ & $0.0 \pm 0 \mathrm{~b}$ & $0.25 \pm 0.05 b$ & $0.0 \pm 0 \mathrm{~b}$ & $0.0 \pm 0 \mathrm{~b}$ & $0.0 \pm 0 \mathrm{~b}$ & $0.8 \pm 0.06 \mathrm{c}$ & $0.02 \pm 0.01 \mathrm{c}$ \\
\hline & T6 & $1.5 \pm 0.07 \mathrm{a}$ & $2.0 \pm 0.8 \mathrm{~b}$ & $0.0 \pm 0 \mathrm{~b}$ & $0.0 \pm 0 \mathrm{~b}$ & $0.0 \pm 0 \mathrm{~b}$ & $3.5 \pm 0.2 \mathrm{c}$ & $0.09 \pm 0.02 \mathrm{c}$ \\
\hline
\end{tabular}

Values are presented as mean \pm SE of five replications. Data in a column followed by different letters are significantly different at the 0.05 levels by Duncan's test.

$109.3 \%$ and $53 \%$ were recorded for the susceptible genotype Lobab. The treatment T4 resulted also in $87.7 \%$ of seed yield increase compared to the control treatment. For resistant genotype Giza 843, respective increases of $27.7 \%$, $17.5 \%, 13.3 \%$, and $6.76 \%$ were recorded for plants subjected to $\mathrm{T} 4, \mathrm{~T} 5, \mathrm{~T} 2$, and $\mathrm{T} 1$ treatments.

Effects of elicitor treatments on $\boldsymbol{O}$. crenata infestation and host development in the pot. The field evaluation was confirmed under controlled conditions by pot assays. During this experiment, the different treatments using both elicitors resulted in a significant variation of $O$. crenata infestation level in both faba bean genotypes (Table 4). Pre-treatment of Lobab seeds with SA (T1) as well as application of a double treatment (T5) resulted in a $100 \%$ control of parasite infestation. Also, both IAA treatments $\mathrm{T} 2$ and $\mathrm{T} 6$ significantly reduced $O$. crenata infestation with respective decreases of $67 \%$ and $59.2 \%$ for the underground Orobanche tubercles and $85 \%$ and $100 \%$ for the emerged Orobanche shoots. For the same treatments, $O$. crenata tubercles dry weight was decreased by $90.5 \%$ and $96.7 \%$ respectively. For the resistant genotype Giza 843 , only the treatments T5 and T6 resulted in a 100\% decrease of emerged Orobanche shoots with significant decreases of the underground tubercles by $91 \%$ and $61 \%$ and Orobanche dry weight by $94.7 \%$ and $76.3 \%$ respectively.

For both tested genotypes, $O$. crenata infestation significantly reduced shoot and roots dry weight of untreated
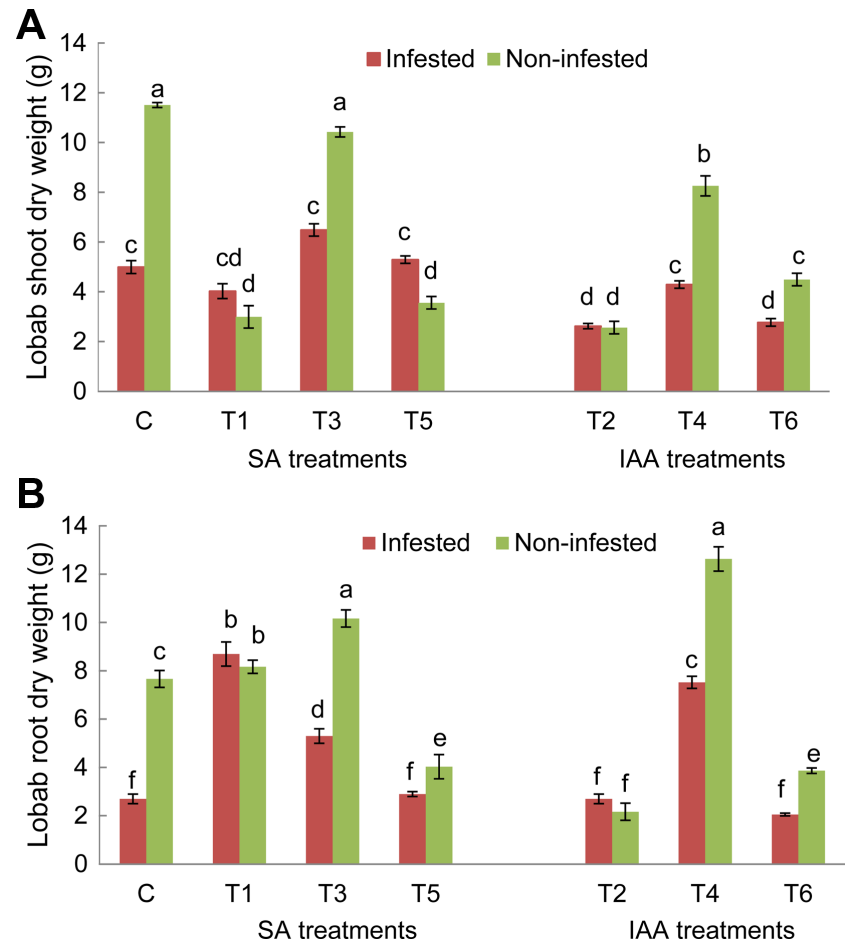

Fig. 2. Shoot (A) and root (B) dry weight (g) of Lobab genotype treated by salicylic acid (SA; $1 \mathrm{mM}$ ) or indole acetic acid (IAA; $0.09 \mathrm{mM}$ ) elicitors assessed in pot assay. Data are means of five replicates for each treatment with SE indicated by vertical lines. Different letters above the bars indicate significantly different means between treatments at the 0.05 levels by Duncan's test. 
A

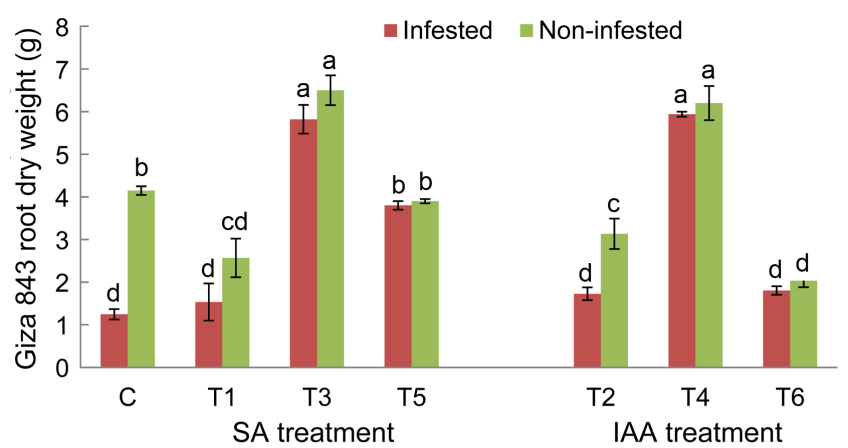

B

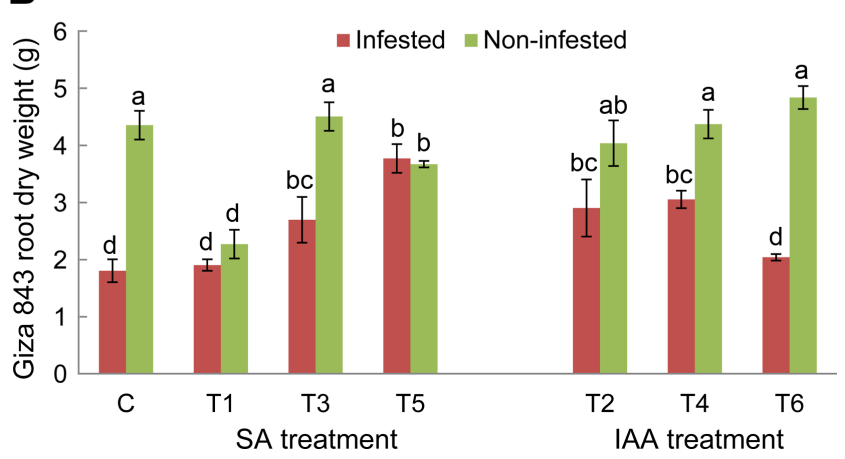

Fig. 3. Shoot (A) and root (B) dry weight (g) of Giza 843 genotype treated by salicylic acid (SA; $1 \mathrm{mM})$ or indole acetic acid (IAA; $0.09 \mathrm{mM}$ ) elicitors assessed in pot assay. Data are means of five replicates for each treatment with SE indicated by vertical lines. Different letters above the bars indicate significantly different means between treatments at the 0.05 levels by Duncan's test.

plants compared to non-infested ones. After application of elicitor treatments, a significant variation of host plant's shoots and roots development was observed (Figs. 2 and 3). For Lobab plants, all applied treatments, except T3 treatment, significantly decreased shoot dry weight of noninfested plants, while, only T2 and T6 treatments resulted in a significant decrease of shoot biomass in infested plants (Fig. 2A). Concerning root dry weight, T1, T4, and T3 treatments resulted in a significant increase for both infested and non-infested plants (Fig. 2B). The respective increase in infested plants was 2.5, 2, and 1.5 times higher than infested control. For Giza 843 plants, T3 and T4 treatments significantly increased shoot dry weight under noninfested conditions. T3 and T4 in addition to T5 treatment also increased the shoot dry weight of infested plants. The respective increase was 4.6, 3, and 4.7 times higher than infested control (Fig. 3A). These three treatments increased also root biomass in infested plants (Fig. 3B).

Total chlorophyll content in response to elicitor treatments. Total chlorophyll content in faba bean leaves of
A
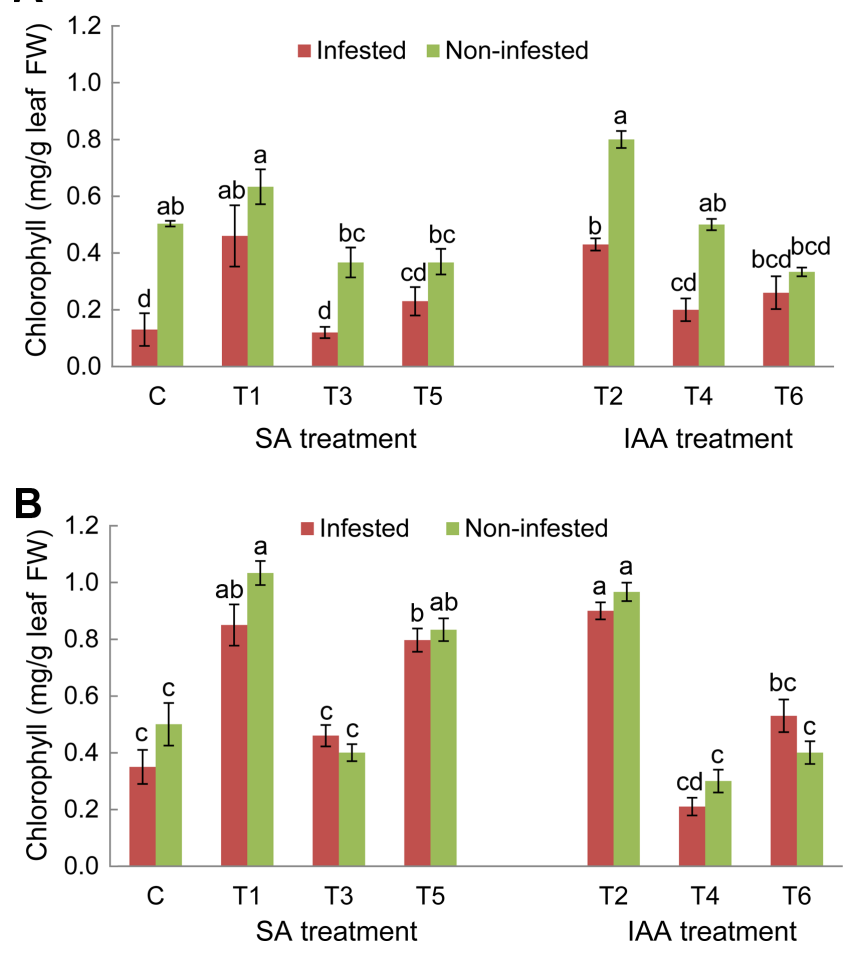

Fig. 4. Leaves chlorophyll contents (mg/g fresh weight [FW]) of Lobab (A) and Giza 843 (B) treated plants by salicylic acid (SA; $1 \mathrm{mM}$ ) or indole acetic acid (IAA; $0.09 \mathrm{mM}$ ) elicitors. Data are means of three replicates for each treatment with SE indicated by vertical lines. Different letters above the bars indicate significantly different means between treatments at the 0.05 levels by Duncan's test.

the two tested genotypes Lobab and Giza 843 showed a significant variation between different treatments (Fig. 4). For susceptible genotype, $O$. crenata parasitism decreased the chlorophyll content by $73.2 \%$ compared to the noninfested control plants. Among elicitor treatments applied, only seed pre-treatments using SA or IAA elicitors (T1 and $\mathrm{T} 2$ treatments) resulted in a significant increase of chlorophyll content in both infested and healthy plants compared to their respective controls (Fig. 4A). Concerning resistant genotype Giza 843, O. crenata infestation didn't affect chlorophyll content of untreated plants compared to the non-infested ones. For this genotype, application of T1, T2, and $\mathrm{T} 5$ treatments significantly increased chlorophyll level in both infested and non-infested treated plants, relative to their respective control plants (Fig. 4B).

Phenolic compounds accumulation in response to elicitors treatment. Analysis of root phenolic contents in control plants of both tested genotypes showed a significant increase of these compounds' concentration in response to 

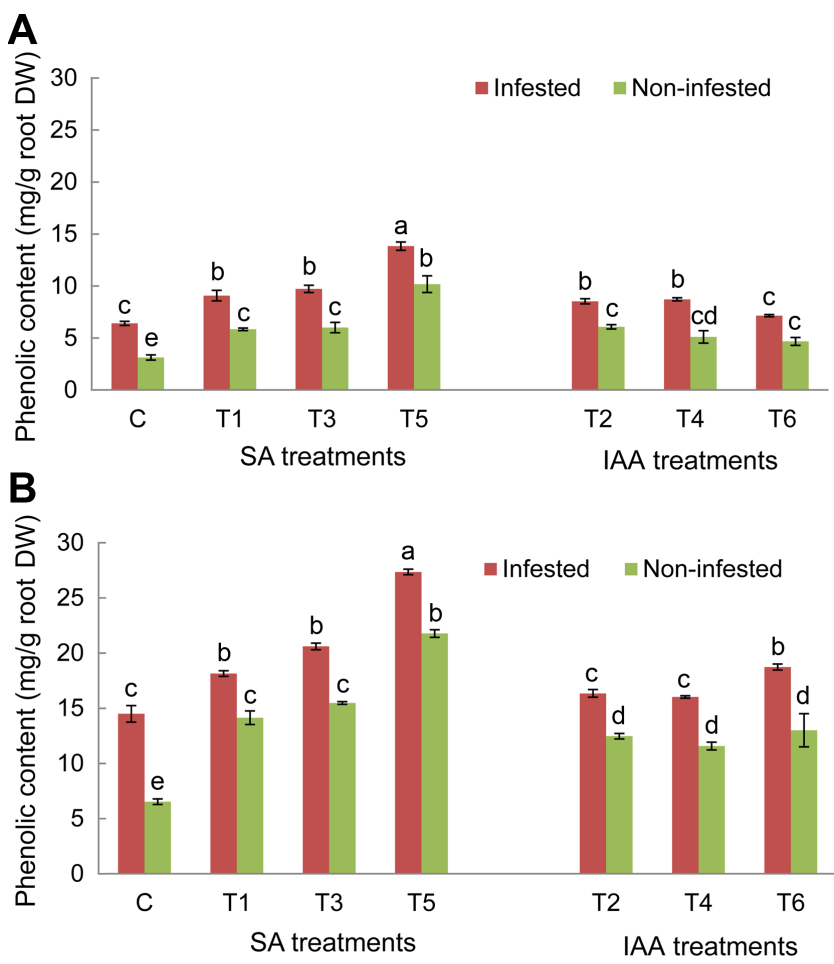

Fig. 5. Root phenolic contents (mg/g root dry weight [DW]) of Lobab (A) and Giza 843 (B) treated plants by salicylic acid (SA; $1 \mathrm{mM}$ ) or indole acetic acid (IAA; $0.09 \mathrm{mM}$ ) elicitors. Data are means of three replicates for each treatment with SE indicated by vertical lines. Different letters above the bars indicate significantly different means between treatments at the 0.05 levels by Duncan's test.

O. crenata infestation compared to non-infested plants. The magnitude of this increase was more obvious in Giza 843 infested plants than Lobab ones (Fig. 5). Application of different elicitor treatments on both genotypes significantly $(P$ $<0.05$ ) increased the phenolic compounds' production and accumulation in non-infested and infested plants as compared to their respective controls (Fig. 5). The increase was higher in resistant genotype Giza 843 than susceptible one (Lobab). Moreover, the phenolic concentration increase in both genotypes was more pronounced in the infested than in the non-infested plants. Among applied treatments, T5 treatment generated the maximum phenolic concentration in both genotypes (Fig. 5A and B).

PAL, POX, and PPO activities in response to elicitors treatment. For both faba bean genotypes, results showed significant variations $(P \leq 0.05)$ of PAL, POX, and PPO activities depending of experimental conditions (noninfested/infested) and the applied treatments (Figs. 6 and 7). Under infested conditions, PAL, POX, and PPO enzyme activities in untreated plants of both genotypes significantly
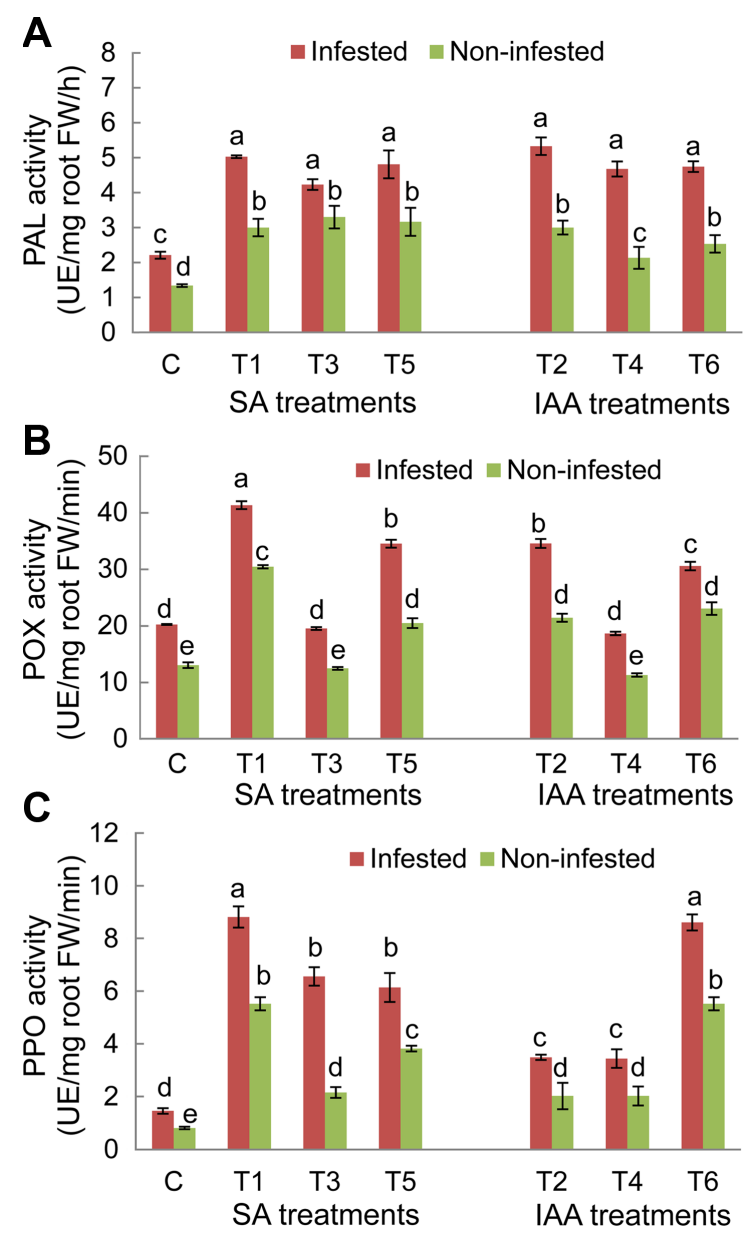

Fig. 6. Phenylalanine ammonia lyase (PAL) (A), peroxidase (POX) (B), and polyphenol oxidase (PPO) (C) activities in roots of Lobab plants treated by salicylic acid (SA; $1 \mathrm{mM})$ or indole acetic acid (IAA; $0.09 \mathrm{mM}$ ) elicitors. FW, fresh weight. Data are means of three replicates for each treatment with SE indicated by vertical lines. Different letters above the bars indicate significantly different means between treatments at the 0.05 levels by Duncan's test.

increased compared to non-infested plants. The magnitude of this increase in O. crenata-infested plants was more obvious in the Giza 843 genotype than theLobabgenotype. PAL and PPO activities were almost 2 times higher in infested Giza 843 control plants than in Lobab plants. Elicitor treatments applied on both faba bean genotypes resulted in significant increase of PAL and PPO activities in infested and non-infested plants compared to their respective controls. The magnitude of this increase was higher in infested than non-infested plants. Moreover, the effect of treatments on these two enzymes activities was more pronounced in plants of the resistant genotype (Figs. 6 and 7).

Concerning POX enzyme in Lobab roots, its activity significantly increased under both infested and non-infested 
A
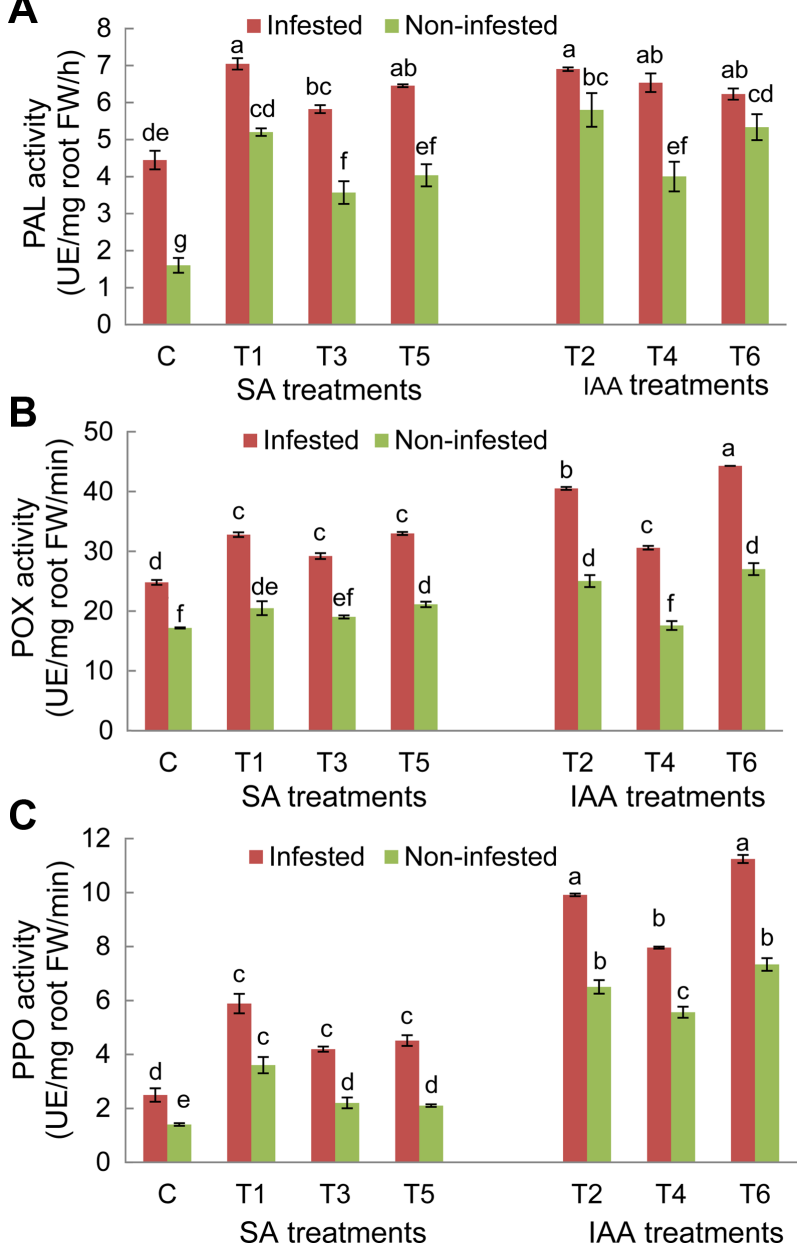

Fig. 7. Phenylalanine ammonia lyase $(\mathrm{PAL})(\mathrm{A})$, peroxidase (POX) (B), and polyphenol oxidase (PPO) (C) activities in roots of Giza 843 plants treated by salicylic acid (SA; $1 \mathrm{mM}$ ) or indole acetic acid (IAA; $0.09 \mathrm{mM}$ ) elicitors. FW, fresh weight. Data are means of three replicates for each treatment with SE indicated by vertical lines. Different letters above the bars indicate significantly different means between treatments at the 0.05 levels by Duncan's test.

conditions in response to $\mathrm{T} 1, \mathrm{~T} 2, \mathrm{~T} 5$, and $\mathrm{T} 6$ treatments. However, no significant effects were recorded on POX activity, in plants subjected to T3 and T4 treatments (Fig. $6 B)$. For resistant genotype Giza 843, POX activity was increased in response to all applied treatments under infested conditions and in response to only $\mathrm{T} 1, \mathrm{~T} 2, \mathrm{~T} 5$, and $\mathrm{T} 6$ treatments under non-infested conditions (Fig. 7B).

Histological study. Examination of faba bean root/O crenata tubercle junctions in both tested genotypes revealed several structural differences between treated and untreated genotypes (Fig. 8). In untreated susceptible genotype (Lobab), parasite cambial cells surrounded host root.
Furthermore, the parasite intrusive cells were able to enter the root epidermis and grow perpendicularly through the cortex and endodermis then directly into the host central cylinder, suggesting the presence of vascular conduits. (Fig. $8 \mathrm{~A}$ and $\mathrm{B})$. However, in untreated resistant genotype Giza 843 , O. crenata haustorium penetrated the root epidermis and cortex but is halted at the endodermis layer. The intrusive cells crushed the root endodermis layer but failed to penetrate it. At this point, the boundary walls between the haustorium and the host cortex were dark colored (Fig. 8C). After application of SA or IAA on Lobab and Giza 843 by seed pre-treatment, an accumulation of dark material inside Lobab root cortex and apoplast was observed (Fig. 8D). The Dark secretions were also observed in Giza 843 root cortex and vascular cylinder (Fig. 8E). Fig. 8E shows also that the parasite cells were scarcely able to pierce the epidermis layer of IAA pre-treated Giza 843 root concomitant with a dark secretion at the apoplast interface close to parasite attachment site.

\section{Discussion}

Parasitic plant $O$. crenata is considered among the most devastating constraint for faba bean production in many countries in the Mediterranean regions (Amri et al., 2019; Briache et al., 2019; Ennami et al., 2017; Rubiales, 2018). During the last decades, research activities on Orobanche control were intensified with focus on the physical and biochemical host-parasite interface including the parasite seed germination stimulant and inhibitors, host plant roots physical barrier and root architecture (Abbes et al., 2009; Fernández-Aparicio et al., 2014; Pérez-de-Luque et al., 2010; Trabelsi et al., 2017). Among all the tested control methods, only genetic resistance and chemical control resulted in a successful control of the parasite with a significant decrease of Orobanche infestation level (Rubiales and Fernández-Aparicio, 2012). The genetic resistance seems to be the most promising control strategy in respect to the environment, which is not the case for chemical method using especially glyphosate. The use of eco-friendly chemicals such as elicitors and resistance inducers for strengthening plant health and plant defense mechanisms are being sought. Many reviews reported elicitors induced resistance as a suitable strategy enhancing natural plant defense against pathogens including fungi, bacteria, viruses and parasitic weed (Abbes et al., 2014; Achuo et al., 2004; Sillero et al., 2012; Šindelářová et al., 2002; Triki et al., 2018).

Under field conditions, seed pre-treatment using both elicitors SA or IAA resulted in a significant reduction of $O$. 

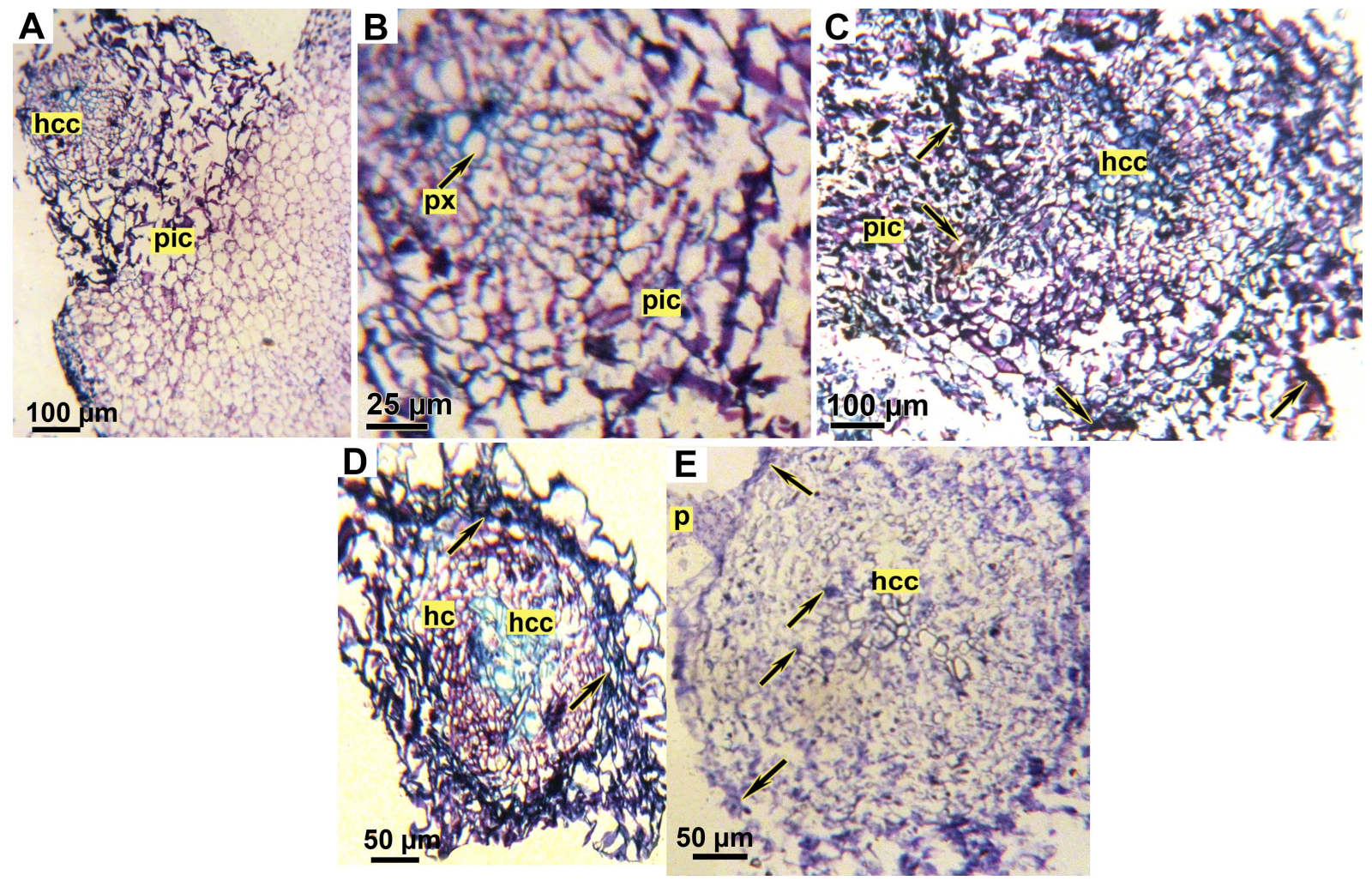

Fig. 8. Microscopic observations of transversal sections of faba bean roots infested by Orobanche crenata stained with \% toluidine blue. (A) Cross section of untreated susceptible genotype (Lobab) showing a successful attachment and penetration of $O$. crenata. (B) Detail of A showing $O$. crenata cells has reached the host xylem vessels. (C) Cross section of an unsuccessful parasite penetration on untreated resistant genotype (Giza 843) showing denied entrance of $O$. crenata haustorium through the root endodermis. (D) Cross section of SA pre-treated root of susceptible genotype (Lobab). Arrows indicate the dark secretions observed in the root cortex and apoplast. (E) Cross section of an unsuccessful parasite penetration on indole acetic acid pre-treated root of resistant genotype (Giza 843). The host cortex has been crushed but the endodermis remains intact, thus rejecting the intruding parasite cells. Arrows indicate the dark secretions observed in the root cortex and inside vascular cylinder. hc, host cortex; hcc, host central cylinder; $p$, parasite; pic, parasite intrusive cells; px, parasite xylem.

crenata infestation for both tested genotypes. Such reductions, compared to the control treatments, were concomitant with the seed yield increases. These results illustrate the beneficial effect of the two used elicitors on activating and enhancing natural host plant resistance against the parasite. Al-Wakeel et al. (2012) reported a significant positive effect of $1 \mathrm{mM}$ of SA or $0.09 \mathrm{mM}$ of IAA seed pre-treatment on tomato $O$. ramosa infestation. Other studies reported that $1 \mathrm{mM}$ of SA seed pre-treatment was more effective in controlling $O$. foetida infestation in faba bean compared to foliar spraying (Triki et al., 2018). Our results didn't show a significant reduction of $O$. crenata infestation in response to foliar treatments. These results are different from those reported by Abbes et al. (2014), who described a significant reduction of $O$. foetida infestation on faba bean plants treated with $1 \mathrm{mM}$ SA which could be explained by the activation of different resistance mecha- nisms against both Orobanche species. Combined seed pre-treatment with foliar application resulted in a significant decrease of $O$. crenata infestation for both genotypes. Foliar necrosis indicating phytotoxicity was observed for IAA double treated plants under field and pot experiment conditions, which could be explained by a negative additive effect of the IAA treatments on seeds and leaves. Seed pre-treatment with SA or IAA combined or not with foliar application decreased the number of both underground and emerged $O$. crenata tubercles. Several studies reported similar results with IAA, SA and derivatives such us BTH and acibenzolar-S-methyl on $O$. foetida infesting faba bean plants (Abbes et al., 2014), O. crenata on pea (Pérezde-Luque et al., 2004), P. ramosa on tobacco, rapeseed, and hemp (Gonsior et al., 2004; Véronési et al., 2009), $O$. cumana on sunflower (Buschmann et al., 2005), and $P$. aegyptiaca on Arabidopsis thaliana (Bar-Nun et al., 2007). 
In faba beans, such treatments reduced Orobanche infestation by delaying tubercle formation and development. Abbes et al. (2014) indicated that reduction of established $O$. foetida in faba bean caused by SA or BTH treatments could be related to reduction of $O$. foetida seed germination by reducing the production of germination stimulants or increasing inhibitors release by the host plant roots. Other studies reported that chemical resistance inducers did not interfere with Orobanche seed germination but restricted Orobanche attachment on the host root (Kusumoto et al., 2007; Pérez-de-Luque et al., 2004; Sauerborn et al., 2002; Véronési et al., 2009).

$O$. crenata seems to act as a competing sink for assimilate with the host plants by compromising the efficiency of carbon assimilation via a reduction of leaf chlorophyll content. This finding was also reported by Ennami et al. (2020) where $O$. crenata parasitism had a significant effect on photosynthetic rates of faba bean especially during late stages of $O$. crenata infestation. In our study, faba bean seed pre-treatment with either SA or IAA improved agrophysiological behavior of the susceptible genotype Lobab under $O$. crenata infested conditions with a significant increase of root growth, seed yield and leaf chlorophyll content. Similar results were reported in tomato infested with $P$. ramosa where SA or IAA seed pre-treatment significantly reduced infestation level and improved tomato root growth and leaf chlorophyll content (Al-Wakeel et al., 2012). Other studies reported also, that treatment of seed host plants with elicitors resulted in a decrease of Orobanche infestation accompanied by a reduction of the host's shoot growth and biomass production (Abbes et al., 2014; Bigirimana and Höfte, 2002; Lopez and Lucas, 2002; Perez et al., 2003; Triki et al., 2018). As reported by Ennami et al. (2020), this could be a result of plant growth-defense tradeoff where part of plant resources, originally allocated to growth, was used for defense purposes.

Phenolic compounds are metabolic products that are frequently synthetized by plants during development and in response to a variety of biotic and abiotic stresses (Stalikas, 2007). Conformingly, our results showed, that resistant faba bean genotype Giza 843 exhibited higher accumulation of phenolic compounds under $O$. crenata infestation, in compared to the susceptible genotype Lobab. Pérez-deLuque et al. (2004) reported similar results with resistant pea genotypes in response to $O$. crenata infestation. In fact, Pradeep and Jambhale (2012) suggested that phenolic compounds and related oxidative enzymes are the most important biochemical actors during disease resistance process. Under non-infested and infested conditions, SA or IAA treatment of both resistant and susceptible genotypes increased the level of phenolic compounds in roots. This result indicates that the host resistance against $O$. crenata could be a result of involvement of phenolic compounds after elicitation by SA or IAA treatments. Similarly, effects of exogenous elicitors application on phenolics accumulation under P. ramosa and Fusarium oxysporum infested conditions have been reported on tomato plants (Ojha and Chatterjee, 2012). It has been reported that phenolic compounds may impede parasite infestation by increasing the mechanical strength of the host cell wall. Also, some phenolic compounds are suggested to be toxic to pathogens and their accumulation at the infestation site has been correlated with the restriction of pathogen development (Benhamou et al., 2000; Rispail et al., 2007).

As with all biotic and abiotic stresses, parasitic weeds infestation induces oxidative stress. To endure oxidative damage under unfavorable conditions, plants possess both non-enzymatic and enzymatic antioxidants such as PAL, POX, and PPO (Smirnoff, 1993). PAL is a key enzyme of the phenylpropanoid pathway that plays a significant role in the phenolic biosynthesis regulation in stressed plant via Shikimate pathway. Induction of PAL is correlated with increased resistance to pathogenic infestation (Wang and Zhang, 2010; Yamunarani et al., 2004). POX are present in all plants species and have many diverse functions, including $\mathrm{H}_{2} \mathrm{O}_{2}$ detoxification and formation of reactive oxygen species. These toxic intermediates cause an oxidative burst in response to pathogens leading to lignin biosynthesis that forms the structural barrier against invading pathogens (Kösesakal and Ünal, 2009; Passardi et al., 2004; Polle et al., 1994). PPO enhances the oxidation of phenolic acids into O-quinons which are more toxic (Chrzanowski et al., 2003). In the present work, results showed that resistant genotype Giza 843, in contrast with susceptible genotype Lobab, was characterized by a high PAL, POX, and PPO activities in normal conditions. For this genotype, O. crenata infestation further increased the activity of theses enzymes. Under various stresses, the high activity of antioxidant enzymes has been reported in several tolerant/ resistant cultivars indicating the important role of these enzymes in imparting tolerance against biotic and abiotic stresses (Pérez-de-Luque et al., 2006; Reddy et al., 2004). In our study, plant treatment with SA and IAA stimulated PAL and PPO activities in both studied genotypes under non-infested and $O$. crenata infested conditions. However, POX activity increased only in response to SA or IAA seed pre-treatment or foliar treatment combined with seed pretreatment. These stimulatory effects confirm the effectiveness of SA and IAA treatments in improving the resistance of faba bean plants against $O$. crenata. For the specific pa- 
thotype host plant Orobanche interaction, only few studies reported antioxidant enzymes' status of plants in response to chemical elicitor treatment. An increase of PAL, POX, and PPO activities was recorded as a response to SA or IAA treatments in P. ramosa infested tomato plants (AlWakeel et al., 2013). Other studies reported a significant effect of chemical elicitors on increasing antioxidant enzymes activities leading to improved plant resistance against pathotypes with different host plant-pathogen interactions (Banerjee et al., 2016; Nascimento et al., 2014; Ojha and Chatterjee, 2012; Ragab et al., 2009).

It is well documented that the ability of Orobanche haustorium to penetrate the host endodermis roots through vascular system presents the most important mechanism for functional parasitism by this parasite (Fernández-Aparicio et al., 2008; Pérez-de-Luque et al., 2005). In some resistant plants, once Orobanche attached, the host can detect the presence of this foreign organism and react accordingly. This reaction occurs during the early stages of the penetration and it could manifest through three forms (Katoch et al., 2005). The cortical resistance is the first resistance preventing haustorium penetration into the host roots. It has often been presented as an apoplastic secretion of brown substances suggesting lignification (Pérez-de-Luque et al., 2005), suberisation (Echevarría-Zomeño et al., 2006), and protein cross-linking (Echevarría-Zomeño et al., 2006; Pérez-de-Luque et al., 2006) of host cortex and xylem cells preventing attachment of the parasite. If the haustorium passing through the cortex, endodermal resistance can be established by the host in order to prevent penetration of Orobanche haustorium to the vascular cylinder. It has been represented as lignification of host pericycle and endodermis layers (Goldwasser et al., 2000; Pérez-de-Luque et al., 2005). The same authors, showed that once the parasite overcomes endodermic barrier, vessel occlusion by secretion of substances containing carbohydrates and polyphenols occurs to reduce water and nutrient leakages to the parasite and lead to tubercle necrosis (Pérez-de-Luque et al., 2005, 2006). Our histological observations showed that in the untreated susceptible genotype Lobab, the parasite haustorium penetrated through the endodermis into the host vascular cylinder. While in SA and IAA seed pre-treated plants, the haustorium was blocked at the root endodermis suggesting that these chemical elicitors enhanced endodermal resistance, presumably through the secretion of specific substances. This resistance reaction form has been also observed in untreated resistant genotype Giza 843 . The SA seed pre-treatment of this latter genotype improved its resistance by reinforcement of host cortex preventing and/or limiting the attachment of the parasite. Blocking $O$. crenata haustorium at the epidermis layer could be related to the secretion and accumulation of chemical material that prevents the parasite from establishing and leading to degeneration or death of the parasite as described by Labrousse et al. (2004) and Pérez-de-Luque et al. (2006).

Anatomical investigations carried out by Pérez-de-Luque et al. (2005) ascribed that, in $O$. crenata resistant vetch, the apoplast and xylem host vessels were filled by a mucilage mainly composed by carbohydrates (non-esterified pectins), blocking the parasite supply channels and leading to the death of the established parasite tubercles. Other studies conducted on tomato reported that biological and chemical elicitors increased the resistance to broomrape through the reinforcement of cell wall and the induction of phenolic compounds and lignin production (Kusumoto et al., 2007; Mandal and Mitra, 2007).

In conclusion, the present study reveals that pre-soaking faba bean seeds in both hormonal inducers SA and IAA have the potential to induce systemic resistance in faba bean against $O$. crenata. This response could contribute to the improvement of faba bean yield within $O$. crenata infested areas. In this respect, it would be necessary to adjust doses and treatment method. Induction of SAR will provide an additional asset to the genetic resistance against Orobanche. Combining these two control strategies will provide more tools for Orobanche management in faba bean, there by avoiding environmental impact of chemical treatments.

\section{Acknowledgments}

This research was supported by National Institute of Agricultural Research (INRA-Morocco) and Ministry of Higher Education, Scientific Research and Professional Training of Morocco (MESRSFC) through funding of "MEDILEG project within the European Union 7th Framework program for research, technological development and demonstration (ERA-Net Project, ARIMNet).

\section{References}

Abbes, Z., Kharrat, M., Delavault, P., Chaïbi, W. and Simier, P. 2009. Nitrogen and carbon relationships between the parasitic weed Orobanche foetida and susceptible and tolerant faba bean lines. Plant Physiol. Biochem. 47:153-159.

Abbes, Z., Kharrat, M., Delavault, P., Simier, P. and Chaïbi, W. 2007. Field evaluation of the resistance of some faba bean (Vicia faba L.) genotypes to the parasitic weed Orobanche foetida Poiret. Crop Prot. 26:1777-1784.

Abbes, Z., Mkadmi, M., Trabelsi, I., Amri, M. and Kharrat, M. 2014. Orobanche foetida control in faba bean by foliar appli- 
cation of benzothiadiazole (BTH) and salicylic acid. Bulg. J. Agric. Sci. 20:1439-1443.

Abd El-Aty, M. S. M., El-Galaly, O. A. M. and Soliman, A. A. M. 2016. Heterosis and combining ability for yield, yield components and inheritance of tolerance to Orobanche in Faba bean. Egypt. J. Plant Breed. 20:397-412.

Abu-Irmaileh, B. E. and Labrada, R. 2014. The problem of Orobanche spp. in Africa and Near East Online: Food and Agriculture Organization of the United Nations (FAO) (2014). URL: http://www.fao.org/agriculture/crops/thematic-sitemap/ theme/biodiversity/weeds/issues/oro/en/ [1 June 2014].

Achuo, E. A., Audenaert, K., Meziane, H. and Höfte, M. 2004. The salicylic acid-dependent defence pathway is effective against different pathogens in tomato and tobacco. Plant Pathol. 53:65-72.

Al-Wakeel, S. A. M., Moubasher, H., Gabr, M. M. A. and Madany, M. M. Y. 2012. Induction of systemic resistance in tomato plants against Orobanche ramosa L. using hormonal inducers. Egypt. J. Bot. 52:403-416.

Al-Wakeel, S. A. M., Moubasher, H., Gabr, M. M. and Madany, M. M. Y. 2013. Induced systemic resistance: an innovative control method to manage branched broomrape (Orobanche ramosa L.) in tomato. IUFS J. Biol. 72:9-21.

Amri, M., Abbes, Z., Trabelsi, I. and Kharrat, M. 2019. Release of a new faba bean variety "Chourouk" resistant to the parasitic plants Orobanche foetida and O. crenata in Tunisia. Int. J. Agric. Biol. 23:499-505.

Banerjee, A., Das, A. B. and Mittra, B. 2016. Aluminium pretreatment induces activation of defense responses against $\mathrm{Fu}$ sarium infection in Triticum aestivum. Russ. J. Plant Physiol. 63:483-489.

Bar-Nun, N., Sachs, T. and Mayer, A. M. 2007. A role for IAA in the infection of Arabidopsis thaliana by Orobanche aegyptiaca. Ann. Bot. 101:261-265.

Benhamou, N., Gagn, S., Le Quér, D. and Dehbi, L. 2000. Bacterial-mediated induced resistance in cucumber: beneficial effect of the endophytic bacterium Serratia plymuthica on the protection against infection by Pythium ultimum. Phytopathology $90: 45-56$.

Bigirimana, J. and Höfte, M. 2002. Induction of systemic resistance to Colletotrichum lindemuthianum in bean by a benzothiadiazole derivative and rhizobacteria. Phytoparasitica 30:159-168.

Briache, F. Z., Ennami, M., Mbasani-Mansi, J., Gaboun, F., Abdelwahd, R., Fatemi, Z. E. A., El-Rodeny, W., Amri, M., Triqui, Z. E. A. and Mentag, R. 2019. Field and controlled conditions screenings of some faba bean (Vicia faba L.) genotypes for resistance to the parasitic plant Orobanche crenata Forsk. and investigation of involved resistance mechanisms. $J$. Plant Dis. Prot. 126:211-224.

Burdziej, A., Da Costa, G., Gougeon, L., Le Mao, I., Bellée, A., Corio-Costet, M.-F., Mérillon, J.-M., Richard, T., Szakiel, A. and Cluzet, S. 2019. Impact of different elicitors on grapevine leaf metabolism monitored by $1 \mathrm{H}$ NMR spectroscopy. Me- tabolomics 15:67.

Buschmann, H., Fan, Z.-W. and Sauerborn, J. 2005. Effect of resistance-inducing agents on sunflower (Helianthus annuus L.) and its infestation with the parasitic weed Orobanche cumana Wallr. J. Plant Dis. Prot. 112:386-397.

Chrzanowski, G., Ciepiela, A. P., Sprawka, I., Sempruch, C., Sytykiewicz, H. and Czerniewicz, P. 2003. Activity of polyphenoloxidase in the ears of spring wheat and triticale infested by grain aphid (Sitobion avenae [F.]). Electron. J. Pol. Agric. Univ. 6:1-5.

Clarke, J. D., Volko, S. M., Ledford, H., Ausubel, F. M. and Dong, X. 2000. Roles of salicylic acid, jasmonic acid, and ethylene in cpr-induced resistance in Arabidopsis. Plant Cell 12:2175-2190.

Durrant, W. E. and Dong, X. 2004. Systemic acquired resistance. Annu. Rev. Phytopathol. 42:185-209.

Echevarría-Zomeño, S., Pérez-de-Luque, A., Jorrín, J. and Maldonado, A. M. 2006. Pre-haustorial resistance to broomrape (Orobanche cumana) in sunflower (Helianthus annuus): cytochemical studies. J. Exp. Bot. 57:4189-4200.

Ennami, M., Briache, F. Z., Mansi, J. M., Gaboun, F., Ghaouti, L., Belqadi, L. and Mentag, R. 2017. Genetic diversity of Moroccan Orobanche crenata populations revealed by sequencerelated amplified polymorphism markers. J. Agric. Sci. 9:164175.

Ennami, M., Mbasani-mansi, J., Briache, F. Z., Oussible, N., Gaboun, F., Ghaouti, L., Belqadi, L., Ghanem, M. E., Aberkani, K., Westwood, J. and Mentag, R. 2020. Growth-defense tradeoffs and source-sink relationship during both faba bean and lentil interactions with Orobanche crenata Forsk. Crop Prot. 127:104924.

Fadeel, A. A. 1962. Location and properties of chloroplasts and pigment determination in roots. Physiol. Plant. 15:130-146.

Fernández-Aparicio, M., Reboud, X. and Gibot-Leclerc, S. 2016. Broomrape weeds. Underground mechanisms of parasitism and associated strategies for their control: a review. Front. Plant Sci. 7:135.

Fernández-Aparicio, M., Kisugi, T., Xie, X., Rubiales, D. and Yoneyama, K. 2014. Low strigolactone root exudation: a novel mechanism of broomrape (Orobanche and Phelipanche spp.) resistance available for faba bean breeding. J. Agric. Food Chem. 62:7063-7071.

Fernández-Aparicio, M., Sillero, J. C., Pérez-de-Luque, A. and Rubiales, D. 2008. Identification of sources of resistance to crenate broomrape (Orobanche crenata) in Spanish lentil (Lens culinaris) germplasm. Weed Res. 48:85-94.

Goldwasser, Y., Plakhine, D., Kleifeld, Y., Zamski, E. and Rubin, B. 2000. The differential susceptibility of vetch (Vicia spp.) to Orobanche aegyptiaca: anatomical studies. Ann. Bot. 85:257262.

Gonsior, G., Buschmann, H., Szinicz, G., Spring, O. and Sauerborn, J. 2004. Induced resistance: an innovative approach to manage branched broomrape (Orobanche ramosa) in hemp and tobacco. Weed Sci. 52:1050-1053. 
Gravel, V., Antoun, H. and Tweddell, R. J. 2007. Effect of indoleacetic acid (IAA) on the development of symptoms caused by Pythium ultimum on tomato plants. Eur. J. Plant Pathol. 119:457-462.

Habimana, S., Nduwumuremyi, A. and Chinama, R. J. D. 2014. Management of orobanche in field crops: a review. J. Soil Sci. Plant Nutr. 14:43-62.

Katoch, R., Mann, A. P. S. and Sohal, B. S. 2005. Enhanced enzyme activities and induction of acquired resistance in pea with elicitors. J. Veg. Sci. 11:67-83.

Kösesakal, T. and Ünal, M. 2009. Role of zinc deficiency in photosynthetic pigments and peroxidase activity of tomato seedlings. IUFS J. Biol. 68:113-120.

Kusumoto, D., Goldwasser, Y., Xie, X., Yoneyama, K., Takeuchi, Y. and Yoneyama, K. 2007. Resistance of red clover (Trifolium pratense) to the root parasitic plant Orobanche minor is activated by salicylate but not by jasmonate. Ann. Bot. 100:537544.

Labrousse, P., Arnaud, M. C., Griveau, Y., Fer, A. and Thalouarn, P. 2004. Analysis of resistance criteria of sunflower recombined inbred lines against Orobanche cumana Wallr. Crop Prot. 23:407-413.

Lopez, A. M. Q. and Lucas, J. A. 2002. Effects of plant defence activators on anthracnose disease of cashew. Eur. J. Plant Pathol. 108:409-420.

Mandal, S. and Mitra, A. 2007. Reinforcement of cell wall in roots of Lycopersicon esculentum through induction of phenolic compounds and lignin by elicitors. Physiol. Mol. Plant Pathol. 71:201-209.

Monci, F., García-Andrés, S., Sánchez-Campos, S., FernándezMuñoz, R., Díaz-Pendón, J. A. and Moriones, E. 2019. Use of systemic acquired resistance and whitefly optical barriers to reduce tomato yellow leaf curl disease damage to tomato crops. Plant Dis. 103:1181-1188.

Nascimento, K. J. T., Debona, D., França, S. K. S., Gonçalves, M. G. M., DaMatta, F. M. and Rodrigues, F. 2014. Soybean resistance to Cercospora sojina infection is reduced by silicon. Phytopathology 104:1183-1191.

Ojha, S. and Chatterjee, N. C. 2012. Induction of resistance in tomato plants against Fusarium oxysporum f. sp. lycopersici mediated through salicylic acid and Trichoderma harzianum. J. Plant Prot. Res. 52:220-225.

Passardi, F., Penel, C. and Dunand, C. 2004. Performing the paradoxical: how plant peroxidases modify the cell wall. Trends Plant Sci. 9:534-540.

Pérez-de-Luque, A., Eizenberg, H., Grenz, J. H., Sillero, J. C., Ávila, C., Sauerborn, J. and Rubiales, D. 2010. Broomrape management in faba bean. Field Crops Res. 115:319-328.

Pérez-de-Luque, A., González-Verdejo, C. I., Lozano, M. D., Dita, M. A., Cubero, J. I., González-Melendi, P., Risueño, M. C. and Rubiales, D. 2006. Protein cross-linking, peroxidase and $\beta$-1,3-endoglucanase involved in resistance of pea against Orobanche crenata. J. Exp. Bot. 57:1461-1469.

Pérez-de-Luque, A., Jorrín, J. V. and Rubiales, D. 2004. Crenate broomrape control in pea by foliar application of benzothiadiazole (BTH). Phytoparasitica 32:21.

Pérez-de-Luque, A., Rubiales, D., Cubero, J. I., Press, M. C., Scholes, J., Yoneyama, K., Takeuchi, Y., Plakhine, D. and Joel, D. M. 2005. Interaction between Orobanche crenata and its host legumes: unsuccessful haustorial penetration and necrosis of the developing parasite. Ann. Bot. 95:935-942.

Perez, L., Rodriguez, M. E., Rodriguez, F. and Roson, C. 2003. Efficacy of acibenzolar-S-methyl, an inducer of systemic acquired resistance against tobacco blue mould caused by Peronospora hyoscyami f. sp. tabacina. Crop Prot. 22:405-413.

Polle, A., Otter, T. and Seifert, F. 1994. Apoplastic peroxidases and lignification in needles of Norway spruce (Picea abies L.). Plant Physiol. 106:53-60.

Pradeep, T. and Jambhale, N. D. 2012. Relationship between phenolics, polyphenol oxidase and peroxidases and resistance to powdery mildew in Zizhyphus. Indian Phytopathol. 55:195196.

Raasch-Fernandes, L. D., Bonaldo, S. M., de Jesus Rodrigues, D., Vieira-Junior, G. M., Schwan-Estrada, K. R. F., da Silva, C. R., Verçosa, A. G. A., de Oliveira, D. L. and Debiasi, B. W. 2019. Induction of phytoalexins and proteins related to pathogenesis in plants treated with extracts of cutaneous secretions of southern Amazonian Bufonidae amphibians. PLoS ONE 14:e0211020.

Ragab, M. M. M., Saber, M. M., El-Morsy, S. A. and El-Aziz, A. R. M. A. 2009. Induction of systemic resistance against root rot of basil using some chemical inducers. Egypt. J. Phytopathol. 37:59-70.

Ramakrishna, R., Sarkar, D. and Shetty, K. 2019. Metabolic stimulation of phenolic biosynthesis and antioxidant enzyme response in dark germinated barley (Hordeum vulgare L.) sprouts using bioprocessed elicitors. Food Sci. Biotechnol. 28:1093-1106.

Reddy, A. R., Chaitanya, K. V., Jutur, P. P. and Sumithra, K. 2004. Differential antioxidative responses to water stress among five mulberry (Morus alba L.) cultivars. Environ. Exp. Bot. 52:33-42.

Rispail, N., Dita, M.-A., González-Verdejo, C., Pérez-de-Luque, A., Castillejo, M.-A., Prats, E., Román, B., Jorrín, J. and Rubiales, D. 2007. Plant resistance to parasitic plants: molecular approaches to an old foe. New Phytol. 173:703-712.

Rubiales, D. 2018. Can we breed for durable resistance to broomrapes? Phytopathol. Mediterr. 57:170-185.

Rubiales, D. and Fernández-Aparicio, M. 2012. Innovations in parasitic weeds management in legume crops: a review. Agron. Sustain. Dev. 32:433-449.

Ryals, J. A., Neuenschwander, U. H., Willits, M. G., Molina, A., Steiner, H.-Y. and Hunt, M. D. 1996. Systemic acquired resistance. Plant Cell 8:1809-1819.

Sauerborn, J., Buschmann, H., Ghiasi, K. G. and Kogel, K.-H. 2002. Benzothiadiazole activates resistance in sunflower (Helianthus annuus) to the root-parasitic weed Orobanche cuman. Phytopathology 92:59-64. 
Sesták, Z. 1971. Determination of chlorophyll a and b. In: Plant photosynthetic production: manual of methods, eds. by Z. Sesták, J. Catsk and P. G. Jarvis, pp. 672-697. Junk N.V., The Hague, Netherlands.

Sillero, J. C., Rojas-Molina, M. M., Ávila, C. M. and Rubiales, D. 2012. Induction of systemic acquired resistance against rust, ascochyta blight and broomrape in faba bean by exogenous application of salicylic acid and benzothiadiazole. Crop Prot. 34:65-69.

Šindelářová, M., Šindeláŕ, L. and Burketová, L. 2002. Glucose6-phosphate dehydrogenase, ribonucleases and esterases upon tobacco mosaic virus infection and benzothiodiazole treatment in tobacco. Biol. Plant. 45:423-432.

Singleton, V. L., Orthofer, R. and Lamuela-Raventós, R. M. 1999. [14] Analysis of total phenols and other oxidation substrates and antioxidants by means of folin-ciocalteu reagent. Methods Enzymol. 299:152-178.

Smirnoff, N. 1993. The role of active oxygen in the response of plants to water deficit and desiccation. New Phytol. 125:2758.

Solecka, D. and Kacperska, A. 2003. Phenylpropanoid deficiency affects the course of plant acclimation to cold. Physiol. Plant. 119:253-262.

Stalikas, C. D. 2007. Extraction, separation, and detection methods for phenolic acids and flavonoids. J. Sep. Sci. 30:32683295.

Thakur, M. and Sohal, B. S. 2013. Role of elicitors in inducing resistance in plants against pathogen infection: a review. ISRN Biochem. 2013:762412.

Trabelsi, I., Yoneyama, K., Abbes, Z., Amri, M., Xie, X., Kisugi, T., Kim, H. I. and Kharrat, M. 2017. Characterization of strigolactones produced by Orobanche foetida and Orobanche crenata resistant faba bean (Vicia faba L.) genotypes and effects of phosphorous, nitrogen, and potassium deficiencies on strigolactone production. S. Afr. J. Bot. 108:15-22.

Triki, E., Trabelsi, I., Amri, M., Nefzi, F., Kharrat, M. and Abbes, Z. 2018. Effect of benzothiadiazole and salicylic acid resistance inducers on Orobanche foetida infestation in Vicia faba. Tunis. J. Plant Prot. 13:113-125.

Ueno, M., Kumura, Y., Ueda, K., Kihara, J. and Arase, S. 2011. Indole derivatives enhance resistance against the rice blast fungus Magnaporthe oryzae. J. Gen. Plant Pathol. 77:209213.

Véronési, C., Delavault, P. and Simier, P. 2009. Acibenzolar-Smethyl induces resistance in oilseed rape (Brassica napus L.) against branched broomrape (Orobanche ramosa L.). Crop Prot. 28:104-108.

Walters, D. R. and Fountaine, J. M. 2009. Practical application of induced resistance to plant diseases: an appraisal of effectiveness under field conditions. J. Agric. Sci. 147:523-535.

Walters, D. R., Ratsep, J. and Havis, N. D. 2013. Controlling crop diseases using induced resistance: challenges for the future. $J$. Exp. Bot. 64:1263-1280.

Wang, Y. and Zhang, Y. 2010. Salicylic acid induces the accumulation of defense-related enzymes in Whangkeumbae pear and protects from pear black spot. Front. Agric. China 4:215219.

Xu, B. J. and Chang, S. K. C. 2007. A comparative study on phenolic profiles and antioxidant activities of legumes as affected by extraction solvents. J. Food Sci. 72:S159-S166.

Yamunarani, K., Jaganathan, R., Bhaskaran, R., Govindaraju, P. and Velazhahan, R. 2004. Induction of early blight resistance in tomato by Quercus infectoria gall extract in association with accumulation of phenolics and defense-related enzymes. Acta Physiol. Plant. 26:281-290. 